Review Article

Human and Medical Genetics

\title{
NDUFV1 mutations in complex I deficiency: Case reports and review of symptoms
}

\author{
Vanessa Zanette ${ }^{1}$ (D), Daniel do Valle ${ }^{2}$ (D), Bruno Augusto Telles ${ }^{2}$, Alan J. Robinson ${ }^{3}$, Vaneisse Monteiro ${ }^{2}$ (D), \\ Mara Lucia S. F. Santos ${ }^{2}$, Ricardo Lehtonen R. Souza ${ }^{1}$ (D) and Cristiane Benincá ${ }^{1,3}$ (I) \\ ${ }^{1}$ Universidade Federal do Paraná, Departamento de Genética, Laboratório de Polimorfismos e Ligação, \\ Curitiba, PR, Brazil. \\ ${ }^{2}$ Hospital Pequeno Príncipe, Divisão de Neuropediatria, Curitiba, PR, Brazil. \\ ${ }^{3}$ University of Cambridge, Medical Research Council, Mitochondrial Biology Unit, Cambridge, \\ United Kingdom.
}

\begin{abstract}
Mitochondrial complex I (Cl) deficiency is the most common oxidative phosphorylation disorder described. It shows a wide range of phenotypes with poor correlation within genotypes. Herein we expand the clinics and genetics of $\mathrm{Cl}$ deficiency in the brazilian population by reporting three patients with pathogenic (c.640G>A, c.1268C>T, c.1207dupG) and likely pathogenic (c.766C $>\mathrm{T}$ ) variants in the NDUFV1 gene. We show the mutation $\mathrm{c} .766 \mathrm{C}>\mathrm{T}$ associated with a childhood onset phenotype of hypotonia, muscle weakness, psychomotor regression, lethargy, dysphagia, and strabismus. Additionally, this mutation was found to be associated with headaches and exercise intolerance in adulthood. We also review reported pathogenic variants in NDUFV1 highlighting the wide phenotypic heterogeneity in $\mathrm{Cl}$ deficiency.
\end{abstract}

Keywords: Leigh Syndrome, mitochondrial diseases, metabolic acidosis, encephalomyopathies.

Received: May 19, 2021; Accepted: August 18, 2021

\section{Introduction}

Dysfunctions in complex I (NADH ubiquinone dehydrogenase) (CI) represents a third of all early-onset mitochondrial disorders and are genetically and clinically diverse (Hirst, 2013). They are caused by mutations in mitochondrial and nuclear genes, with clinical phenotypes ranging from severe lactic acidosis and death in infants to muscle weakness in adults. Five clinical groups were associated with CI deficiency: Leigh syndrome, progressive leukoencephalopathy, neonatal cardiomyopathy, severe infantile lactic acidosis, and a miscellaneous group of unspecified encephalomyopathies (Fassone and Rahman, 2012). Correlations between genotype and phenotype in mitochondrial diseases are not fully understood and need further exploration (Baertling et al., 2018)

$\mathrm{CI}$ is a protein complex composed of 44 different subunits, seven of which are encoded by mitochondrial DNA (mtDNA) and the remaining by nuclear DNA (nDNA) (Hirst, 2013). CI catalyzes the oxidation of nicotinamide adenine dinucleotide (NADH) in the mitochondrial matrix, supplying electrons to complex III via reduction of coenzyme Q. The electron flux through CI sustains the translocation of four protons across the inner mitochondrial membrane, thus contributing to the mitochondrial electrochemical potential. CI is also an important source of reactive oxygen species (ROS) in

Send correspondence to Vanessa Zanette. Universidade Federal do Paraná, Departamento de Genética, Laboratório de Polimorfismos e Ligação, Av. Cel. Francisco H. dos Santos 100, 81530-000, Curitiba, PR, Brazil. E-mail: vanessa.bioinfo@gmail.com. mitochondria, which causes cellular oxidative stress (Murphy, 2009). CI is subdivided into three modules: the electron input (N) module, the electron output $(\mathrm{Q})$ module, and the proton translocations $(\mathrm{P})$ module. The $\mathrm{N}$ module is composed of subunits encoded by the genes NDUFV1, NDUFV2, and NDUFS1 (Brandt, 2006). The NDUFVI gene (NG_013353.1) is located on chromosome 11 and encodes the NADHubiquinone oxidoreductase flavoprotein (NM_007103.4), a hydrophilic polypeptide of $51 \mathrm{kDa}$, which oxidizes NADH and is a major site of ROS production (Hirst, 2013; Varghese et al., 2015)

In this report, we presented three patients with mutations in the NDUFVI gene. The first patient is a compound heterozygous for a missense mutation c.640G $>$ A (p.Glu214Lys) and a frameshift mutation c.1207dupG (p.Asp403Gly*fs), the second is homozygous for a missense mutation c. $1268 \mathrm{C}>\mathrm{T}$ (p.Thr423Met), and the third, combining the c.1268C $>\mathrm{T}$ (p.Thr423Met) and a likely pathogenic variant c.766C $>\mathrm{T}$ (p.Arg256Cys).

\section{Methods}

This work received the approval of the ethical standards committee of the Federal University of Paraná (CAAE: 84773818.2.0000.0102).

Total DNA was extracted from blood using the DNeasy Kit (Qiagen, Hilden, DE). Whole Exome Sequencing (WES) was carried out using Illumina ${ }^{\circledR} 2000$ HiSeq with Agilent SureSelect Human All Exon V7 for the first two cases, and Nextera $^{\circledR}$ Exome Capture to third, the GRCh37 reference genome and a GATK-based pipeline was used to call, filter and annotate variants (Van der Auwera et al., 2013). After 
identification of relevant variants, the region containing each variant was re-sequenced and family segregation was performed by Sanger sequencing.

The position of the mutations was mapped to the corresponding amino acids in the protein structures of Bos taurus (NM_174808.1) and human (PDB ID: 5XTB). The impact of the mutated amino acids on CI was investigated by visualizing the mutations in the context of the CI structures (Zhu et al., 2016) by using the PyMOL structure viewer.

MR imaging and MR spectroscopy of the brain were performed with a 1.5-T MR unit (GE Medical Systems, Milwaukee, WI). T1-weighted images [echo time (TE)/ repetition time (TR) $11 \mathrm{~ms} / 550 \mathrm{~ms}$, T2-weighted images (TE/TR $93 \mathrm{~ms} / 4000 \mathrm{~ms}$ ), fluid-attenuated inversion recovery (FLAIR) (TE/TR/inversion time $110 \mathrm{~ms} / 10000 \mathrm{~ms} / 2250 \mathrm{~ms}$ ) and diffusion-weighted images (DWI) (TE/TR: 105 ms/5200 $\mathrm{ms})$ were performed. Spectroscopic imaging was performed with long (144 ms) and short TE (35 ms).

The pathogenicity was predict by SNPs\&GO (Calabrese et al., 2009), PolyPhen-2 (Ramensky et al., 2002) e MutationTaster (Schwarz et al., 2014) and allele frequency was searched in Exome Aggregation Consortium (EXAC) (Lek et al. 2016), 1000genomes (Consortium T 1000 GP, 2015), gnomAD (Karczewski et al., 2020) AbraOM (Naslavsky et al., 2017), TopMed (Taliun et al., 2021) and Kaviar (Glusman et al., 2011). Association between mutation c.766C $>\mathrm{T}$ and symptoms in family members of patient P3 were estimated by Chi-Square test with Monte Carlo simulations by using the R program.

\section{Results}

\section{Case reports}

\section{Patient P1}

Patient $1(\mathrm{P} 1)$, male, 4 years old, was born by cesarean delivery at 40 weeks of gestation with $3760 \mathrm{~g}$. The mother presented three previous miscarriages (8-, 8- and 12-weeks' gestation) and placenta detachment during P1 pregnancy with indication of resting. The father presented childhood seizures and no consanguinity was reported. P1 had three healthy brothers, two of whom were maternal half-brothers.

P1 was 3 years old when he presented developmental delay and autistic spectrum disorder and was admitted to the hospital after episodic vomiting and dehydration associated with a cutaneous rash. After treatment P1 developed respiratory insufficiency needing orotracheal intubation. Viral encephalitis was evaluated with negative outcomes in cerebrospinal fluid (CSF), however empiric treatment with Acyclovir for 14 days showed complete recovery of neurological symptoms, with normal daily activities and no functional impairment. Brain MRI was performed after treatment and showed T2-weighted hyperintense and T1-weighted hypointense focal lesions in central portions of the upper segment of the cervical spinal cord, with additional symmetric lesions in midbrain, pons, and bulb.

One month later, P1 was admitted to the hospital with prostration, nausea, vomiting and absence seizures, developing a cutaneous rash and apnea after two days. Orotracheal intubation was performed and extubation failure occurred due to the persistency of apnea, therefore, tracheostomy and gastrostomy were performed. Arterial blood gas analysis, blood lactate, blood acylcarnitine's profile, urinary organic acids, and blood amino acid chromatography were normal. The patient continued to have recurrent apneas, but no seizures. A new MRI showed increased hyperintense lesions in T2 and hypointense lesions in T1, affecting the central portions of the upper segment of the cervical spinal cord (Figure 1, P1: A-B). Symmetric lesions also increased when compared with the first MRI, mainly affecting the mesencephalon, pons, medulla oblongata, cerebellum and upper portions of the cervical spinal cord with an elevation of lactate detected by MR spectroscopy (Figure 1, P1: C).

Based on the hypothesis of mitochondrial disease, treatment was started with coenzyme Q10 (CoQ) $(300 \mathrm{mg} /$ day) and L-carnitine (100 mg/kg/day). At 4 years old, P1 presented slight clinical improvement with apnea stabilization, progressive drowsiness reduction and progress in wakefulness.

\section{Patient P2}

Patient 2 (P2), male, 11 years old, was born by cesarean delivery at 38 weeks of gestation with $2470 \mathrm{~g}, 45 \mathrm{~cm}$ height and $33.5 \mathrm{~cm}$ head circumference. Pregnancy was uneventful and no symptoms were reported in the first four months of life. The mother was 46 years old when pregnant and presented one previous miscarriage. P2 had a deceased 5 years old sister with a clinical history of seizures, and a healthy older sister. Parents were consanguineous (first degree cousins).

At 4 months old, $\mathrm{P} 2$ presented minor cervical hypotonia and mild right hemibody hypertonia. At 7 years of age, he started to present developmental delay, aggressive behavior, learning difficulties, and motor regression. An organic acid profile in urine showed 3-methylglutaconic aciduria. He was admitted to hospital in the same year due to lethargy alternated with irritability and needed orotracheal intubation with mechanical ventilation after apnea. Tracheostomy was performed due to the extubation failure.

When P2 was 11 years old, he presented optic atrophy, sensorineural deafness, ptosis, hypotonia, hyperreflexia with diplegic spasticity, dysphagia and hyperhidrosis. Similar brain MRI patterns were seen in P2 at the age of 7 (Figure 1, P2: A) and 10 (Figure 1, P2: B) years. The second MRI showed hyperintensity in T2/FLAIR/T2 in the thalamus, lentiform nucleus, frontal lobe, and a lactate peak at spectroscopy (Figure 1, P2: C). Current treatment includes CoQ (300 mg/ day), L-carnitine (2 g/day), carbamazepine $(17.5 \mathrm{mg} / \mathrm{kg} /$ day $)$, biotin $(20 \mathrm{mg} /$ day $)$, creatine ( $2 \mathrm{~g} /$ day $)$, clobazam $(0.4 \mathrm{mg} / \mathrm{kg} /$ day), baclofen (15 mg/day), vitamin $\mathrm{C}$ and $\mathrm{B}$ complex and $\mathrm{P} 2$ is in a stable clinical condition.

\section{Patient P3}

Patient 3 (P3), female, 3 years old, the younger of two siblings from non-consanguineous parents. The mother had 4 pregnancies, with one miscarriage at 10 weeks. P3 had uneventful perinatal history, she was born at term, and had no clinical symptoms. Neurodevelopment milestones were normal up to 9 months old when she developed progressive hypotonia and somnolence, followed by a gradual loss of motor skills in the following month. Cerebrospinal fluid was 

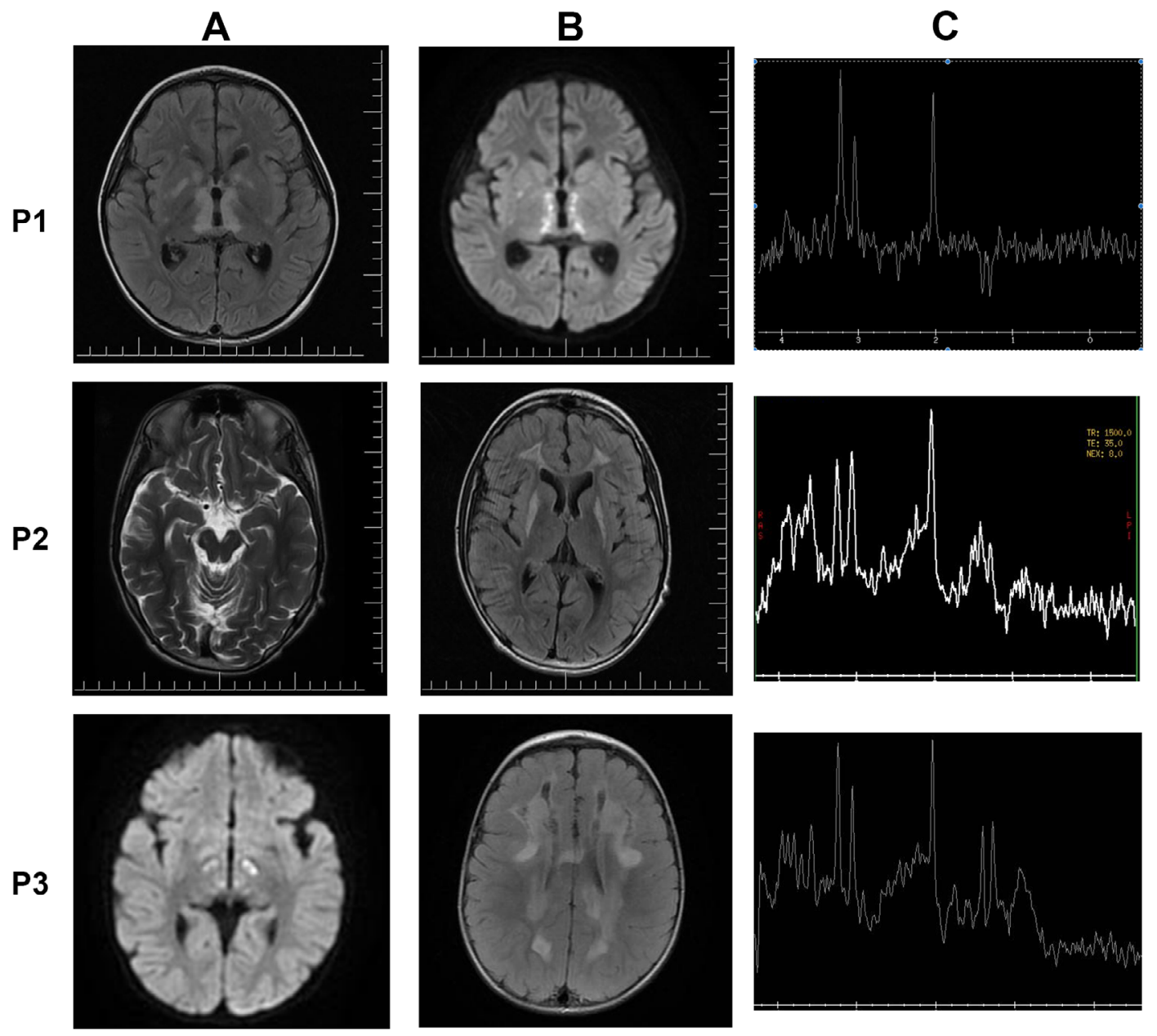

Figure 1 - Clinical features of the patients. (A and B) MRI of patients P1, P2 and P3 showing white matter changes and symmetric lesions in different regions of the brain, red arrow indicated altered brain region. (C) Elevated lactate in each patient measured by MR spectroscopy, indicated by red arrow.

negative for markers of viral infection. Her sister was healthy, however, her father presented epilepsy in infancy and frequent headaches in adulthood.

The first diagnostic hypothesis for $\mathrm{P} 3$ was acute disseminated encephalitis, showing normal electroencephalogram, diffuse white matter lesions by MRI and a lactate peak on spectroscopy (Figure 1, P3: A-C). Symptoms improved after treatment with methylprednisolone for three days, with an improvement of the symptoms. However, after a week, a gradual clinical decline was observed with lethargy, dysphagia and general hypotonia. After 13 months, a new MRI (not shown) showed increased white matter lesions, suggesting a mitochondrial disorder. An acylcarnitine profile in blood showed increased concentrations of 3-hydroxy-butyrylcarnitine and acetylcarnitine, amino acid chromatography showed increased alanine (656.1, normal $146-494 \mathrm{mcmol} / \mathrm{L})$. Lactate levels in plasma ranged from 2.7 to 7.6 (normal $<2.2 \mathrm{mmol} / \mathrm{L}$ ) over one year. Lactic acid levels in cerebrospinal fluid were often increased, ranging from 3.5 to 5.3 (normal $<0.8 \mathrm{mmol} / \mathrm{L}$ ). Levels of urinary organic acids were normal. Supplementation with CoQ and carnitine was started but with no significative improvement. At 3 years old, P3 lost neurodevelopmental milestones and developed hypotonia, strabismus and severe inappetence.
She was submitted to an endoscopic gastrostomy and current treatment was based on supplementation with CoQ, creatine, sodium bicarbonate, acetyl L-carnitine, riboflavin, and biotin.

\section{Genetic analysis}

$\mathrm{P} 1$ revealed the heterozygous mutations c.640G $>\mathrm{A}$ (p.Glu214Lys) of maternal inheritance and c.1207dupG (p.Asp403Glyfs*27) from paternal inheritance in NDUFV1 gene. The allele frequency of p.Glu214Lys was not reported, whereas p.Asp403Glyfs*27 shows a frequency of $0.0008 \%$ (ExAC and gnomAD) and 0.0004 (TOPMED) in control population, the frameshift mutation causes the premature stop codon of the protein in Asp429.

The Glu214 residue was highly conserved among bilaterally symmetrical metazoans (Figure 2A) and was positioned in the interface with the subunit NDUFS4 linked by a hydrogen-bonded (Figure 2B). The mutation p.Glu214Lys disrupted the hydrogen bond and likely destabilized the interface with the neighboring subunit, NDUFS4.

P2 shows the c.1268C $>$ T (p.Thr423Met) mutation in homozygosity in the NDUFVI gene. The highest allele frequency in control population was below $0.01 \%$. The Thr423 residue was highly conserved among bilaterally 
symmetrical metazoans (Figure $2 \mathrm{~A}$ ) and faces the $4 \mathrm{Fe}-4 \mathrm{~S}$ domain of NDUFV1 (Figure 2B). The mutation of threonine to a larger methionine was likely to disturb the assembly of the $4 \mathrm{Fe}-4 \mathrm{~S}$ cluster into the protein or to cause dysfunction in the assembled protein.

WES analysis of $\mathrm{P} 3$ identified the compound heterozygous mutations in the NDUFV1 gene, c.766C $>$ T (p.Arg256Cys) and c. $1268 \mathrm{C}>\mathrm{T}$ (p.Thr423Met). Analysis of the mutations in the family members showed c. $766 \mathrm{C}>\mathrm{T}$ segregating from the father, and c. $1268 \mathrm{C}>\mathrm{T}$ from the mother (Figure $2 \mathrm{C}$ ). Five members of the paternal lineage were carriers for $\mathrm{c} .766 \mathrm{C}>\mathrm{T}$. The mutation c. $766 \mathrm{C}>\mathrm{T}$ caused the missense change p.Arg256Cys with no associated clinical conditions. Allele frequency of this variant corresponded to one heterozygous individual $(0.00001648 \%)$ only and bioinformatic tools predicted this alteration as pathogenic (score 0.99 and 0.87 ). The amino acid arginine in this position was highly conserved in bilaterally symmetrical metazoans (Figure 2A). Arg256 was localized in the tip of the hydrophilic arm of NDUFV1 subunit and this sidechain was not resolved in the protein structure (Figure 2B). Family carriers for p.Arg256Cys presented frequent headaches and exercise intolerance (Figure 2C) with statistically significant (p-value 0.027 ) association between frequent headaches and the mutation was found.

A

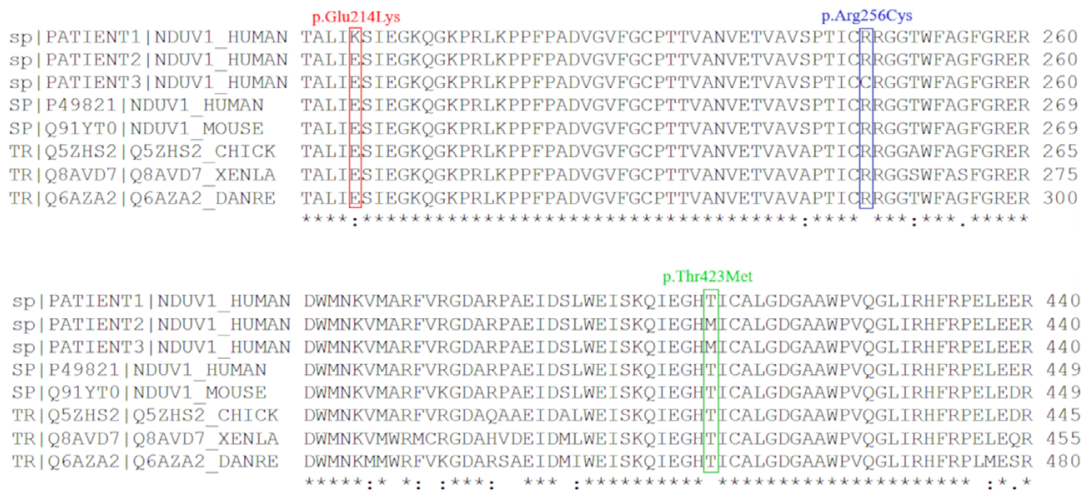

B
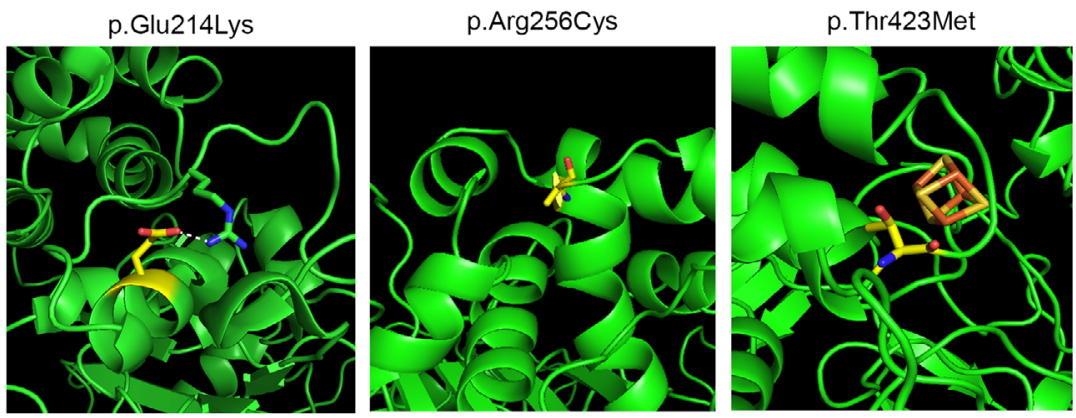

\section{C}

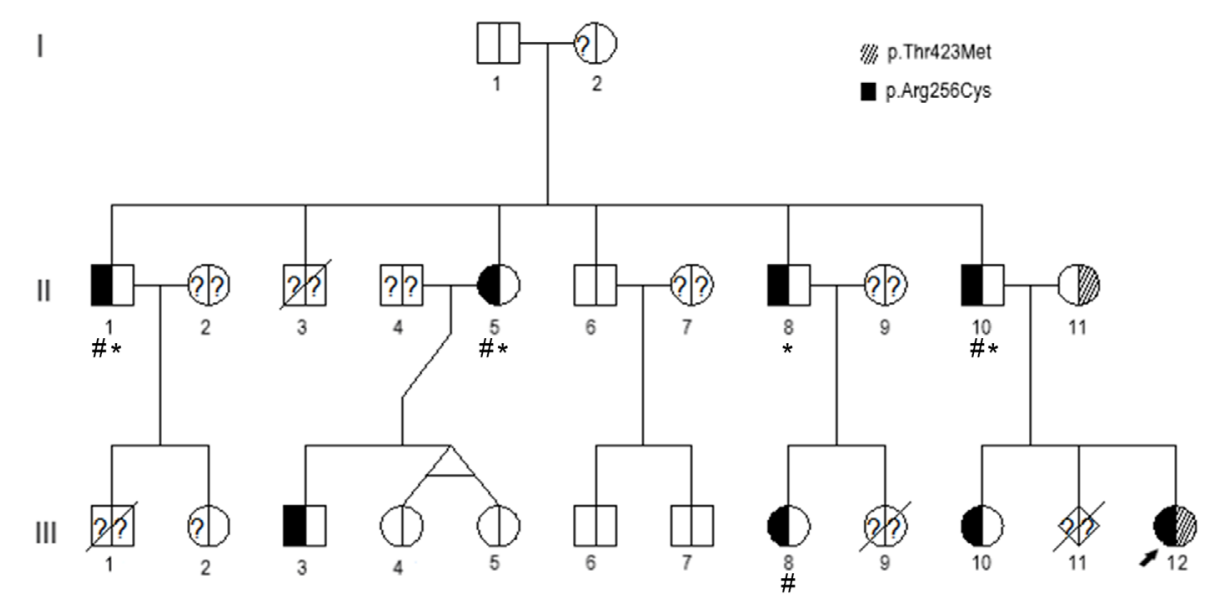

Figure 2 - NDUFV1 protein and mutations. A) Sequence alignment of the NDUFV1 protein from different species. Mutated amino acids were indicated (patient 1:p.Glu214Lys; patient 2: p.Thr423Met; and patient 3: p.Arg256Cys); B) Representation of 3D structure of amino acid changes (p.Thr423Met , p.Arg256Cys and p.Glu214Lys); C) Pedigree of patient 3 (indicated by arrow) and family members affected by mutations c.766 C $>$ T and c.1268C $>$ T in the NDUFV1 gene. Carriers of c.766 C $>$ T present frequent headaches (\#) and mild exercise intolerance $(*)$. 


\section{Literature review}

Several studies described mutations in the NDUFVI gene associated with CI deficiency (Table 1). In this review we found 24 patients with mutations in the NDUFV1 gene, of which 8 were homozygous and 15 were compound heterozygous. The most frequent mutations were c.1268C $>$ T (p.Thr423Met) and c.1156C $>$ T (p.Arg386Cys).

The onset of symptoms ranged from 5 months of age to adulthood. Several common symptoms were described, mainly neuromotor regression, with spasticity, tremors, ataxia, dystonia, seizures, hypotonia, apnea, dysphagia, vomiting, lethargy, ptosis, strabismus, nystagmus, optic atrophy, cognitive decline, autistic behaviors, progressive weakness and exercise intolerance.

The most common features in MRI were hyperintense lesions in $\mathrm{T} 2$ affecting several regions of the brain, white matter changes, brain atrophy, and presence of lactate peak in MR spectroscopy.

Table 1 - Clinical and molecular features of patients presenting NDUFV1 mutations. Nucleotide and amino acid change, clinical phenotype, brain MRI, Het/Hom (Heterozygous or homozygous), segregation and references are described. C.het. (Compound Heterozygous); Hom (Homozygous); Mat. (maternal); Pat. (Paternal); Ref (Reference). Lines in blue: Cases of p.Thr423Met, lines in green: cases of p.Glu214Cys.

\begin{tabular}{|c|c|c|c|c|c|c|}
\hline Nucleotide change & $\begin{array}{l}\text { Amino acid } \\
\text { change }\end{array}$ & $\begin{array}{l}\text { Clinical phenotype } \\
\text { (age of onset) }\end{array}$ & Brain MRI & Het/Hom & Segregation & Ref \\
\hline $\begin{array}{l}\text { c. } 640 \mathrm{G}>\mathrm{A} \\
\text { c. } 1207 \mathrm{dupG}\end{array}$ & $\begin{array}{l}\text { p.Glu214Lys } \\
\text { p.Asp403Gly*fs }\end{array}$ & $\begin{array}{l}\text { Developmental/cognitive } \\
\text { delay, autistic behaviors, } \\
\text { vomits, apnea ( } 3 \mathrm{y} / \mathrm{o})\end{array}$ & $\begin{array}{l}\text { Hyperintense signal } \\
\text { in T2, hypointense } \\
\text { in T1 affecting the } \\
\text { central portions of } \\
\text { the upper segment } \\
\text { of the cervical spinal } \\
\text { cord. Symmetric } \\
\text { lesions affecting } \\
\text { the mesencephalon, } \\
\text { bridge, bulb, } \\
\text { cerebellum. Lactate } \\
\text { peak }\end{array}$ & C. het & $\begin{array}{l}\text { Mat. c. } 640 \mathrm{G}>\mathrm{A} \\
\text { Pat. c. } 1207 \mathrm{dupG}\end{array}$ & Present Report \\
\hline c. $1268 \mathrm{C}>\mathrm{T}$ & p.Thr423Met & $\begin{array}{l}\text { Cervical hypotonia, right } \\
\text { hypertonia, lethargy, apnea } \\
\text { (1 y/o) Optic atrophy, } \\
\text { sensorineuronal deafness, } \\
\text { ptosis, global hypotonia, } \\
\text { hyperreflexia with diplegic } \\
\text { spasticity, dysphagia and } \\
\text { hyperhidrosis (11 y/o) }\end{array}$ & $\begin{array}{l}\text { Hyperintensity in T2/ } \\
\text { FLAIR in thalamus, } \\
\text { lentiform nucleus, } \\
\text { frontal lobe, corpus } \\
\text { callosum knee. } \\
\text { Lactate peak }\end{array}$ & Hom & Both & Present Report \\
\hline $\begin{array}{l}\text { c. } 1268 \mathrm{C}>\mathrm{T} \\
\text { c. } 766 \mathrm{C}>\mathrm{T}\end{array}$ & $\begin{array}{l}\text { p. Thr423Met } \\
\text { p.Arg256Cys }\end{array}$ & $\begin{array}{l}\text { Hypotonia, lethargy, } \\
\text { motor regression and } \\
\text { dysphagia }(10 \mathrm{~m} / \mathrm{o}), \\
\text { neurodevelopmental delay } \\
\text { and strabismus }(2 \mathrm{y} / \mathrm{o})\end{array}$ & $\begin{array}{l}\text { Diffuse white matter } \\
\text { lesions and lactate } \\
\text { peak }\end{array}$ & C. het & $\begin{array}{l}\text { Mat. c. } 1268 \mathrm{C}>\mathrm{T} \\
\text { Pat. c. } 766 \mathrm{C}>\mathrm{T}\end{array}$ & Present Report \\
\hline c. $766 \mathrm{C}>\mathrm{T}$ & p.Arg256Cys & $\begin{array}{l}\text { Infant seizures, exercise } \\
\text { intolerance and frequent } \\
\text { headaches (adulthood) }\end{array}$ & N/A & Het & N/A & Present Report \\
\hline c. $1268 \mathrm{C}>\mathrm{T}$ & p.Thr423Met & $\begin{array}{l}\text { Myopathy, depression, } \\
\text { fatigue (infancy) }\end{array}$ & Normal & Het & Maternal & $\begin{array}{l}\text { Baertling et al., } \\
2018\end{array}$ \\
\hline c. $1268 \mathrm{C}>\mathrm{T}$ & p.Thr423Met & $\begin{array}{c}\text { Horizontal nystagmus, } \\
\text { dysarthria, bilateral } \\
\text { dysmetria and } \\
\text { intention tremor, } \\
\text { dysdiadochokinesia, and } \\
\text { gait } \\
\text { ataxia }(10 \mathrm{y} / \mathrm{o})\end{array}$ & $\begin{array}{l}\text { Bilateral, symmetric, } \\
\text { hyperintense } \\
\text { signal in the putamen } \\
\text { and right caudate } \\
\text { nucleus on T2- } \\
\text { weighted imaging } \\
\text { and a high lactate } \\
\text { peak in the affected } \\
\text { areas }\end{array}$ & Hom & Both & $\begin{array}{l}\text { Incecik et al., } \\
2018\end{array}$ \\
\hline c. $1118 \mathrm{~T}>\mathrm{C}$ & p.Phe73Ser & $\begin{array}{l}\text { CI deficiency symptoms } \\
\text { N/D }(6 \mathrm{~m} / \mathrm{o})\end{array}$ & $\mathrm{N} / \mathrm{D}$ & Hom & Both & $\begin{array}{l}\text { Srivasta } \text { et al., } \\
2018\end{array}$ \\
\hline c. $1156 \mathrm{C}>\mathrm{T}$ & p.Arg386Cys & $\begin{array}{l}\text { Neuroregression, mild } \\
\text { cognitive decline with } \\
\text { regressive speech } \\
\text { deficiencies, bilateral optic } \\
\text { atrophy, and marked motor } \\
\text { decline }(6 \mathrm{y} / \mathrm{o})\end{array}$ & $\begin{array}{l}\text { Diffuse white matter } \\
\text { demyelination } \\
\text { with cystic areas } \\
\text { consistent with } \\
\text { neurodegeneration }\end{array}$ & Hom & Both & $\begin{array}{l}\text { Srivasta et al., } \\
2018\end{array}$ \\
\hline
\end{tabular}


Table 1 - Cont

\begin{tabular}{|c|c|c|c|c|c|c|}
\hline Nucleotide change & $\begin{array}{l}\text { Amino acid } \\
\text { change }\end{array}$ & $\begin{array}{l}\text { Clinical phenotype } \\
\text { (age of onset) }\end{array}$ & Brain MRI & Het/Hom & Segregation & Ref \\
\hline $\begin{array}{l}\text { c. } 1156 \mathrm{C}>\mathrm{T} \\
\text { c. } 155+1 \mathrm{G}>\mathrm{G} / \mathrm{A}\end{array}$ & p.Arg386Cys & $\begin{array}{l}\text { Spasticity of all four } \\
\text { limbs, brisk deep tendon } \\
\text { reflexes and extensor } \\
\text { plantar response, } \\
\text { Ophthalmic evaluation } \\
\text { revealed bilateral } \\
\text { horizontal nystagmus with } \\
\text { normal optic disc }(1 \mathrm{y} / \mathrm{o})\end{array}$ & $\begin{array}{l}\text { Diffuse cystic } \\
\text { leukoencephalopathy } \\
\text { involving corpus } \\
\text { callosum, deep and } \\
\text { periventricular white } \\
\text { matter with sparing } \\
\text { of basal ganglia, } \\
\text { brainstem, and } \\
\text { cerebellum }\end{array}$ & C. het & $\mathrm{N} / \mathrm{D}$ & $\begin{array}{l}\text { Wadhwa et al., } \\
2018\end{array}$ \\
\hline $\begin{array}{l}\text { c. } 605 \mathrm{C}>\mathrm{T} \\
\text { c. } 816 \mathrm{~T}>\mathrm{G}\end{array}$ & $\begin{array}{l}\text { p.Ala202Val } \\
\text { p.His272Gln }\end{array}$ & $\begin{array}{c}\text { Dystonia, increased } \\
\text { muscle tension, MR, left } \\
\text { ventricular high voltage } \\
(21 \mathrm{~m} / \mathrm{o})\end{array}$ & $\begin{array}{l}\text { abnormal signals } \\
\text { in bilateral Basal } \\
\text { ganglia, brain stem } \\
\text { and thalamus }\end{array}$ & C. het & $\begin{array}{l}\text { Mat c. } 605 \mathrm{C}>\mathrm{T} \\
\text { Pat.c. } 816 \mathrm{~T}>\mathrm{G}\end{array}$ & $\begin{array}{l}\text { Fang et al., } \\
\quad 2017\end{array}$ \\
\hline $\begin{array}{l}\text { c. } 1162+4 \mathrm{~A}>\mathrm{C} \\
\text { c. } 640 \mathrm{G}>\mathrm{A}\end{array}$ & p.Gly214Lys & $\begin{array}{l}\text { Seizures, ptosis, scoliosis, } \\
\text { dystonia, }(2 \mathrm{y} / \mathrm{o})\end{array}$ & $\begin{array}{l}\text { Symmetrical } \\
\text { putaminal lesions, } \\
\text { lactate peak, } \\
\text { involvement of the } \\
\text { left, body of the } \\
\text { caudate and the right } \\
\text { quadrigeminal plate }\end{array}$ & C. het & $\begin{array}{c}\text { Pat. c. } 1162+4 \mathrm{~A}>\mathrm{C} \\
\text { Mat. c. } 640 \mathrm{G}>\mathrm{A}\end{array}$ & $\begin{array}{l}\text { Nafisinia et al., } \\
2016\end{array}$ \\
\hline $\begin{array}{l}\text { c. } 365 \mathrm{C}>\mathrm{T} \\
\text { c. } 158 \mathrm{~T}>\mathrm{C}\end{array}$ & $\begin{array}{l}\text { p.Pro122Leu } \\
\text { p.Leu53Pro }\end{array}$ & $\begin{array}{l}\text { Progressive weakness, } \\
\text { epileptic seizures, optic } \\
\text { atrophy, nystagmus, } \\
\text { energy deficiency } \\
\text { intolerance, learning } \\
\text { disability }(6 \mathrm{~m} / \mathrm{o})\end{array}$ & $\begin{array}{l}\text { white matter changes } \\
\text { with leukomalacia } \\
\text { and thinning of the } \\
\text { corpus callosum, } \\
\text { sparing the basal } \\
\text { ganglia }\end{array}$ & C. het & $\begin{array}{l}\text { Mat. c. } 365 \mathrm{C}>\mathrm{T} \\
\text { Pat. c. } 158 \mathrm{~T}>\mathrm{C}\end{array}$ & $\begin{array}{l}\text { Bjorkman et } \\
\text { al., } 2015\end{array}$ \\
\hline $\begin{array}{l}\text { c. } 365 \mathrm{C}>\mathrm{T} \\
\text { c. } 158 \mathrm{~T}>\mathrm{C}\end{array}$ & $\begin{array}{l}\text { p.Pro122Leu } \\
\text { p.Leu53Pro }\end{array}$ & $\begin{array}{l}\text { Irritability, progressive } \\
\text { weakness, epileptic } \\
\text { seizures, optic atrophy, } \\
\text { strabismus, energy } \\
\text { deficiency intolerance, } \\
\text { learning disability } \\
(7 \mathrm{~m} / \mathrm{o})\end{array}$ & $\begin{array}{l}\text { progressive white } \\
\text { matter changes } \\
\text { with cystic malacic } \\
\text { degeneration }\end{array}$ & C. het & $\begin{array}{l}\text { Mat. c. } 365 \mathrm{C}>\mathrm{T} \\
\text { Pat. c. } 158 \mathrm{~T}>\mathrm{C}\end{array}$ & $\begin{array}{l}\text { Bjorkman et } \\
\text { al., } 2015\end{array}$ \\
\hline $\begin{array}{l}\text { c.1156C }>\mathrm{T} \\
\text { c.914-8G_947 }\end{array}$ & p.Arg386Cys & $\begin{array}{l}\text { Inability to sit, poor head } \\
\text { control, spasticity, brisk } \\
\text { reflexes, sustained clonus, } \\
\text { strabismus and nystagmus } \\
\text { (1 y/o) }\end{array}$ & $\begin{array}{l}\text { extensive atrophy } \\
\text { of the white matter }\end{array}$ & C. het & $\begin{array}{c}\text { Pat.r c.1156C>T } \\
\text { Mat. c.914-8G_947 }\end{array}$ & $\begin{array}{l}\text { Recalde } \text { et al. } \\
2013\end{array}$ \\
\hline c. $1156 \mathrm{C}>\mathrm{T}$ & p.Arg386Cys & $\begin{array}{l}\text { Mild titubation, drooling, } \\
\text { increased irritability, axial } \\
\text { hypotonia, lower extremity } \\
\text { hypertonia, diffusely brisk } \\
\text { reflexes and an extensor } \\
\text { plantar response bilaterally } \\
\text { with gait ataxia and } \\
\text { frequent falls }(14 \mathrm{~m} / \mathrm{o})\end{array}$ & $\begin{array}{l}\text { Bilateral symmetric } \\
\text { hyperintense } \\
\text { signal on T2- } \\
\text { weighted imaging } \\
\text { in periventricular } \\
\text { white matter, } \\
\text { centrum semiovale, } \\
\text { corpus callosum, } \\
\text { substantia nigra } \\
\text { and periaqueductal } \\
\text { gray associated } \\
\text { with cystic necrosis, } \\
\text { with a high lactate } \\
\text { peak, decreased } \\
\text { N-acetylaspartic acid } \\
\text { (NAA) peak and } \\
\text { increased choline } \\
\text { peak }\end{array}$ & Hom & Both & $\begin{array}{l}\text { Marin et al., } \\
\quad 2013\end{array}$ \\
\hline c. $1156 \mathrm{C}>\mathrm{T}$ & p.Arg386Cys & $\begin{array}{l}\text { Developmental regression } \\
\text { with intercurrent illness, } \\
\text { left eye esotropia, } \\
\text { dysphagia, ataxia, left } \\
\text { hemi-body dystonic } \\
\text { posturing, generalized } \\
\text { spasticity, diffusely brisk } \\
\text { reflexes, and extensor } \\
\text { plantar responses }(1 \mathrm{y} / \mathrm{o})\end{array}$ & $\mathrm{N} / \mathrm{D}$ & Hom & Both & $\begin{array}{l}\text { Marin et al. } \\
\quad 2013\end{array}$ \\
\hline
\end{tabular}


Table 1 - Cont.

\begin{tabular}{|c|c|c|c|c|c|c|}
\hline Nucleotide change & $\begin{array}{l}\text { Amino acid } \\
\text { change }\end{array}$ & $\begin{array}{l}\text { Clinical phenotype } \\
\text { (age of onset) }\end{array}$ & Brain MRI & Het/Hom & Segregation & Ref \\
\hline $\begin{array}{l}\text { c. } 262 \mathrm{C}>\mathrm{G} \\
\text { c. } 596 \mathrm{G}>\mathrm{C}\end{array}$ & $\begin{array}{l}\text { p.Arg88Gly } \\
\text { p.Arg199Pro }\end{array}$ & $\begin{array}{l}\text { Hypotonia, decreased } \\
\text { spontaneous movements } \\
\text { and hyperreflexia in the } \\
\text { left lower extremity } \\
(32 \mathrm{~m} / \mathrm{o})\end{array}$ & $\begin{array}{l}\text { Symmetrical } \\
\text { restricted diffusion } \\
\text { of the corticospinal } \\
\text { tracts and a lactate } \\
\text { peak on MRS in } \\
\text { the basal ganglia, } \\
\text { thalamus and cortex }\end{array}$ & C. het & $\mathrm{N} / \mathrm{D}$ & $\begin{array}{l}\text { Marin et al., } \\
\quad 2013\end{array}$ \\
\hline $\begin{array}{l}\text { c. } 1156 \mathrm{C}>\mathrm{T} \\
\text { c. } 753 \mathrm{delCCCC}\end{array}$ & $\begin{array}{l}\text { p.Arg386Cys } \\
\text { p.Ser251Ser*fs }\end{array}$ & $\begin{array}{l}\text { Becoming non-verbal, } \\
\text { unable to sit, irritability, } \\
\text { horizontal nystagmus, } \\
\text { dysphagia, tremor, upper } \\
\text { extremity weakness, } \\
\text { axial hypotonia with } \\
\text { appendicular hypertonia, } \\
\text { hyperreflexia, and } \\
\text { extensor plantar responses } \\
\text { bilaterally }(14.5 \mathrm{~m} / \mathrm{o}) \\
\text { Decreased visual acuity, } \\
\text { dysphagia and complex } \\
\text { partial seizures }(7 \mathrm{y} / \mathrm{o})\end{array}$ & $\begin{array}{l}\text { MRIs initially } \\
\text { showed an } \\
\text { improvement in the } \\
\text { white matter signal } \\
\text { changes and new } \\
\text { areas of restricted } \\
\text { diffusion within the } \\
\text { frontal lobes but later } \\
\text { revealed increases } \\
\text { in the abnormal } \\
\text { whitematter signals } \\
\text { with newinvolvement } \\
\text { of the basal ganglia, } \\
\text { diffuse cystic change } \\
\text { and an elevated } \\
\text { lactate peak in the } \\
\text { basal ganglia }\end{array}$ & C. het & N/D & $\begin{array}{l}\text { Marin et al., } \\
\quad 2013\end{array}$ \\
\hline c.G1156A & p.Arg386His & $\begin{array}{l}\text { Recurrent vomiting, } \\
\text { dysphagia and failure to } \\
\text { thrive, axial hypotonia, } \\
\text { tetraparesis without } \\
\text { muscle wasting, } \\
\text { irritability, and a rotatory } \\
\text { nystagmus. } \\
\text { hypoventilation of } \\
\text { increasing intensity } \\
\text { and rapid neurologic } \\
\text { degradation }(3.5 \mathrm{~m} / \mathrm{o})\end{array}$ & $\begin{array}{l}\text { T2 hypersignal and } \\
\text { T1 hyposignal in } \\
\text { the posterior part } \\
\text { of the medulla, the } \\
\text { pons and in the } \\
\text { mesencephalon }\end{array}$ & Hom & Both & $\begin{array}{l}\text { Vilain et al., } \\
\quad 2012\end{array}$ \\
\hline c.G1156A & p.Arg386His & $\begin{array}{l}\text { rotatory nystagmus and } \\
\text { mild peripheral hypotonia, } \\
\text { Feeding difficulties and } \\
\text { respiratory insufficiency } \\
(3.5 \mathrm{~m} / \mathrm{o})\end{array}$ & $\begin{array}{l}\text { discrete symmetric } \\
\text { T2 hypersignal } \\
\text { and T1 hyposignal } \\
\text { lesions in the pons } \\
\text { and the medulla }\end{array}$ & Hom & Both & $\begin{array}{l}\text { Vilain et al., } \\
\quad 2012\end{array}$ \\
\hline $\begin{array}{l}\text { c. } 770 \mathrm{G}>\mathrm{A} \\
\text { c. } 632 \mathrm{~T}>\mathrm{C}\end{array}$ & $\begin{array}{l}\text { p.Arg257Gln } \\
\text { p.Ala211Val }\end{array}$ & $\begin{array}{l}\text { Regression in motor } \\
\text { milestones stopped } \\
\text { crawling and sitting } \\
\text { independently }(9 \mathrm{~m} / \mathrm{o})\end{array}$ & $\begin{array}{l}\text { Periventricular white } \\
\text { matter abnormalities } \\
\text { with sparing of the } \\
\text { subcortical white } \\
\text { matter }\end{array}$ & C. het & N/D & $\begin{array}{l}\text { Zafeiriou et al., } \\
2008\end{array}$ \\
\hline $\begin{array}{l}\text { c. } 640 \mathrm{G}>\mathrm{A} \\
\text { c. } 1192+4 \mathrm{~A}>\mathrm{C}\end{array}$ & p.Glu214Lys & $\begin{array}{c}\text { Seizures }(1 \mathrm{y} / \mathrm{o}) \\
\text { Cerebellar ataxia, } \\
\text { psychomotor regression, } \\
\text { strabismus and ptosis } \\
(28 \mathrm{~m} / \mathrm{o})\end{array}$ & $\begin{array}{l}\text { Brain atrophy } \\
\text { and multiple } \\
\text { symetric areas of } \\
\text { hyperintensity in } \\
\text { brain stem }\end{array}$ & C. het & $\begin{array}{c}\text { Pat. c. } 640 \mathrm{G}>\mathrm{A} \\
\text { Mat. c. } 1192+4 \mathrm{~A}>\mathrm{C}\end{array}$ & $\begin{array}{l}\text { Benit et al., } \\
\quad 2001\end{array}$ \\
\hline c. $1294 \mathrm{G}>\mathrm{C}$ & Ala432Pro & $\begin{array}{l}\text { Vomiting, hypotonia, } \\
\text { lethargy and apnea }(6 \mathrm{~m} / \mathrm{o})\end{array}$ & $\begin{array}{c}\text { areas of } \\
\text { hyperintensity in the } \\
\text { basal ganglia. }\end{array}$ & C. het & $\begin{array}{l}\text { Pat. c.1294G }>\text { C } \\
\text { Mat. c.990_991del }\end{array}$ & $\begin{array}{l}\text { Benit et al., } \\
\quad 2001\end{array}$ \\
\hline $\begin{array}{l}\text { c. } 611 \mathrm{~A}>\mathrm{G} \\
\text { c. } 616 \mathrm{~T}>\mathrm{G}\end{array}$ & $\begin{array}{l}\text { p.Tyr204Cys } \\
\text { p.Cys206Gly }\end{array}$ & $\begin{array}{l}\text { Hypotonia, unable to sit, } \\
\text { ataxia, bilateral ptosis and } \\
\text { ophthalmoplegia }(5 \mathrm{~m} / \mathrm{o})\end{array}$ & $\begin{array}{c}\text { areas of } \\
\text { hyperintensity of the } \\
\text { locus niger }\end{array}$ & C. het & $\begin{array}{l}\text { Pat. c. } 611 \mathrm{~A}>\mathrm{G} \\
\text { Mat. c. } 616 \mathrm{~T}>\mathrm{G}\end{array}$ & $\begin{array}{l}\text { Benit et al., } \\
\quad 2001\end{array}$ \\
\hline $\begin{array}{l}\text { c. } 175 \mathrm{C}>\mathrm{T} \\
\text { c. } 1268 \mathrm{C}>\mathrm{T}\end{array}$ & $\begin{array}{l}\text { p.Arg59X } \\
\text { p.Thr423Met }\end{array}$ & $\begin{array}{l}\text { Strabismus, progressive } \\
\text { muscular hypotonia, } \\
\text { myoclonic epilepsy and } \\
\text { psychomotor regression. } \\
(5 \mathrm{~m} / \mathrm{o} .)\end{array}$ & $\begin{array}{l}\text { cranial MRIs nor } \\
\text { post-mortem reports } \\
\text { were available to } \\
\text { confirm symmetric } \\
\text { midbrain or } \\
\text { brainstem necrosis to } \\
\text { definitively confirm } \\
\text { Leigh syndrome }\end{array}$ & C. het & $\begin{array}{l}\text { Pat. c. } 175 \mathrm{C}>\mathrm{T} \\
\text { Mat. c. } 1268 \mathrm{C}>\mathrm{T}\end{array}$ & $\begin{array}{c}\text { Schuelke et al. } \\
1999\end{array}$ \\
\hline
\end{tabular}


Table 1 - Cont.

\begin{tabular}{|c|c|c|c|c|c|c|}
\hline Nucleotide change & $\begin{array}{l}\text { Amino acid } \\
\text { change }\end{array}$ & $\begin{array}{l}\text { Clinical phenotype } \\
\text { (age of onset) }\end{array}$ & Brain MRI & Het/Hom & Segregation & Ref \\
\hline c. $1022 \mathrm{C}>\mathrm{T}$ & Ala341Val & $\begin{array}{c}\text { infantile myoclonic } \\
\text { epilepsy, spasticity }(6 \mathrm{~m} / \mathrm{o})\end{array}$ & $\begin{array}{l}\text { brain atrophy } \\
\text { and a progressive } \\
\text { macrocystic } \\
\text { leukodystrophy }\end{array}$ & Hom & Both & $\begin{array}{c}\text { Schuelke et al., } \\
1999\end{array}$ \\
\hline c. $1118 \mathrm{C}>\mathrm{T}$ & p.Phe373Ser & $\begin{array}{l}\text { Seizures, myopia, bilateral } \\
\text { lower set ears, nystagmus, } \\
\text { mosaic pigmentary } \\
\text { anomalies, hepatomegaly, } \\
\text { and spasticity in lower } \\
\text { limbs, extreme plantar } \\
\text { responses and brisk deep } \\
\text { tendon reflexes }(6 \mathrm{~m} / \mathrm{o})\end{array}$ & $\begin{array}{c}\text { diffuse hyperintensity } \\
\text { in the cerebral white } \\
\text { matter, cerebellar } \\
\text { white matter and } \\
\text { brainstem white } \\
\text { matter, and small } \\
\text { cystic areas in the } \\
\text { periventricular white } \\
\text { matter }\end{array}$ & Hom & Both & $\begin{array}{c}\text { Schuelke et al., } \\
1999\end{array}$ \\
\hline
\end{tabular}

\section{Discussion}

This work presents three patients with clinical presentation of mitochondrial disease with mutations in the NDUFV1 gene (Table 2). The mutation p.Asp403Glyfs*27 was found in trans with p.Glu214Lys in P1, and the combination of p.Arg256Cys with p.Thr423Met was observed in P3. Both p.Glu214Lys and p.Thr423Met were described as pathogenic and cause CI deficiency (Baertling et al., 2018; Incecik et al., 2018; Srivastava et al., 2018; Wadhwa et al., 2018). The homozygous mutation p.Thr423Met in NDUFV1 gene was found in P2.

The mutation p.Asp403Glyfs*27 leads to a truncated protein with likely functional consequences due to a stop codon preceding the $4 \mathrm{Fe}-4 \mathrm{~S}$ domain (Hirst, 2013), and was not previously associated with mitochondrial disease. Despite this, the frameshift variant should be classified as pathogenic following the ACMG guideline. The variant p.Glu214Lys was previously described as likely pathogenic in a patient with seizures, cerebellar ataxia, and psychomotor regression presenting CI deficiency (Incecik et al., 2018). The phenotype described was different from $\mathrm{P} 1$, which presented a mitochondrial disease phenotype characterized by developmental delay, autistic spectrum disorder, respiratory insufficiency, T1weighted hypointense, symmetric lesions in white matter and presence of lactate peak at spectroscopy. The recurrent apneas, prostation and vomiting led $\mathrm{P} 1$ to hospitalization several times, making artificial respiration necessary, despite this, metabolic and laboratory profiles were normal.

p.Glu214Lys changed a medium-sized acid residue to a large basic amino acid and may prevent hydrogen bonds, thus destabilizing the interface with the subunit NDUFS4. Mutations in this position probably reduce electron transfer through the redox Fe-S centers of CI (Incecik et al., 2018). Modeling of the reported mutation in NDUFV1 suggested a disturbance of the assembly or function of the 4Fe-4S cluster (Fang et al., 2017)

$\mathrm{P} 2$ was identified as homozygous for c. $1268 \mathrm{C}>\mathrm{T}$ (p.Thr423Met) mutation in NUDFV1. This mutation was described leading to myopathy, depression, fatigue, strabismus, progressive muscular hypotonia, myoclonic epilepsy and psychomotor regression. Another case of homozygosity for c. $1268 \mathrm{C}>\mathrm{T}$ was described leading to horizontal nystagmus, dysarthria, bilateral dysmetria and intention tremor, dysdiadochokinesia, and gait ataxia (Wadhwa et al., 2018), a different presentation from $\mathrm{P} 2$, which presented hypotonia, developmental delay, learning difficulties and motor regression, nevertheless presenting a typical mitochondrial disease phenotype with presence of lactate peak in spectroscopy and 3-methylglutaconic aciduria.

P3 presented two compound heterozygous missense mutations, c. 1268C $>$ T (p.Thr423Met), also found in P2, and c. $766 \mathrm{C}>\mathrm{T}$ (p.Arg256Cys) segregating from the father with a clinical history of infant seizures and exercise intolerance with frequent headaches in adulthood. An association of headaches and exercise intolerance was found for the paternal family carriers of c.766C $>$ T, which was statistically significant. Arg256 residue was highly conserved in bilaterally symmetrical metazoans and was localized in the tip of the hydrophilic arm of NDUFV1 subunit, which unfortunately, was not structurally elucidated and further studies are needed for its functional characterization. Despite that c.766C $>\mathrm{T}$ (p.Arg256Cys) is found described in ClinVar as likely pathogenic and, the Arg257 residue, neighboring Arg256, was associated with CI deficiency (Nafisinia et al., 2016). This residue was shown to be essential for protein function and predicted to be post-translationally modified to a N-methylarginine by similarity with the mouse protein (Fang et al., 2017). The variant c.766C $>$ T (p.Arg256Cys) was predicted as pathogenic (score 0.99 and 0.87 ) and we propose that in combination with c. $1268 \mathrm{C}>\mathrm{T}$ (p.Thr423Met), they might be responsible for $\mathrm{P} 3$ phenotype, characterized by a childhood-onset development of hypotonia, muscle weakness, physical exercise intolerance, psychomotor regression, lethargy, dysphagia, and strabismus. The same phenotype was commonly associated with mild CI deficiency (Fassone and Rahman, 2012; Hirst, 2013; Baertling et al., 2018). This phenotype could be explained by a dominant-negative effect of the post-translational modification in the affected region, masking the effect of the wild-type version of the protein.

\section{Conclusion}

CI deficiency was associated with many nuclear and mitochondrial genes, and the understanding of the genetics of this mitochondrial disease has expanded significantly in recent years. Here we described three cases of mutations in the NDUFV1 subunit, associated with mitochondrial disease and possibly CI deficiency. The case reports and the review of NDUFV1 mutations showed heterogeneous phenotypes 
Table 2 - Classification of the variants identified in P1, P2, and P3 according to the ACMG criteria.

\begin{tabular}{|c|c|c|c|c|c|}
\hline Patient & $\begin{array}{c}\text { Location } \\
\text { (Chromossome 11) }\end{array}$ & $\begin{array}{c}\text { Variant } \\
\text { NM_007103.4 }\end{array}$ & Zygosity & Classification (ACMG) & Inheritance \\
\hline \multirow{2}{*}{$P 1$} & 67377981 & $\begin{array}{c}\text { c.640G }>\text { A } \\
\text { (p.Glu214Lys) }\end{array}$ & Heterozygous & $\begin{array}{c}\text { Pathogenic } \\
(\mathrm{PS} 1+\mathrm{PM} 1+\mathrm{PM} 2+\mathrm{PM} 3)\end{array}$ & Maternal \\
\hline & 67379629 & $\begin{array}{c}\text { c.1207dupG } \\
\text { (p.Asp403Glyfs*27) }\end{array}$ & Heterozygous & $\begin{array}{c}\text { Pathogenic } \\
\text { (PVS1+PM2+PM3) }\end{array}$ & Paternal \\
\hline$P 2$ & 67379696 & $\begin{array}{c}\text { c. } 1268 \mathrm{C}>\mathrm{T} \\
\text { (p.Thr423Met) }\end{array}$ & Homozygous & $\begin{array}{c}\text { Pathogenic } \\
\text { (PS1+PS3+PM2) }\end{array}$ & Both \\
\hline \multirow{2}{*}{$P 3$} & 67379696 & $\begin{array}{c}\text { c. } 1268 \mathrm{C}>\mathrm{T} \\
\text { (p.Thr423Met) }\end{array}$ & Comp. Heterozygous & $\begin{array}{c}\text { Pathogenic } \\
\text { (PS1+PS3+PM2) }\end{array}$ & Maternal \\
\hline & 67378531 & $\begin{array}{c}\text { c.766C }>\mathrm{T} \\
\text { (p.Arg256Cys) }\end{array}$ & Comp. Heterozygous & $\begin{array}{c}\text { Likely Pathogenic } \\
\text { (PM2+PM3+PP3+PP4) }\end{array}$ & Paternal \\
\hline
\end{tabular}

and severity. We propose the association of p.Arg256Cys to frequent headaches in family members of P3. Combination of p.Thr423Met and p.Arg256Cys mutations in heterozygosity were sufficient to cause the clinical features of an autosomal recessive CI deficiency, but confirmation of this deficiency by biochemical approaches were not possible and further studies are necessary.

The addition of new mutations to the literature contributes to a better understanding of the etiology of mitochondrial disease, as well as the potential of future correlations between genotype and phenotype, allowing the earlier implementation of mitochondrial dysfunction preventive therapies.

\section{Acknowledgements}

We acknowledge patients and family members for their participation. Davidson Xavier for helping with the images, Dr. Massimo Zeviani and Dr. Caterina Garone for scientific advice. This study was financed in part by the Coordenação de Aperfeiçoamento de Pessoal de Nível Superior - Brasil (CAPES) - Finance Code 001.

\section{Conflict of Interest}

The authors declare that there is no conflict of interest that could be perceived as prejudicial to the impartiality of the reported research.

\section{Author Contributions}

VZ collected and analyzed data, wrote and edited the manuscript, DV collected data, reviewed and edited the manuscript, BAT collected data, reviewed and edited the manuscript, AJR analyzed data, reviewed and edited the manuscript, VM collected data, reviewed and edited the manuscript, MLSFS supervised data collection, reviewed and edited the manuscript, RLRS supervised genetic analysis, reviewed and edited the manuscript, $\mathrm{CB}$ conceptualized, supervised data collection and analysis, writing and revision of the manuscript. All authors read and approved the final version of the manuscript.

\section{References}

Baertling F, Sánchez-Caballero L, van den Brand MAM, Distelmaier F, Janssen MCH, Rodenburg RJT, Smeitink JAM and Nijtmans LGJ (2018) A heterozygous NDUFV1 variant aggravates mitochondrial complex i deficiency in a family with a homoplasmic ND1 variant. J Pediatr 196:309-313.
Bénit P, Chretien D, Kadhom N, Cormier-Daire V, Cabral A, Peudenier S, Rustin P, Munnich A and Rötig A (2001) Largescale deletion and point mutations of the nuclear NDUFV1 and NDUFS1 genes in mitochondrial complex I deficiency. Am J Hum Genet 68:1344-1352.

Björkman K, Sofou K, Darin N, Holme E, Kollberg G, Asin-Cayuela J, Dahle KMH, Oldfors A, Moslemi AR and Tulinius M (2015) Broad phenotypic variability in patients with complex I deficiency due to mutations in NDUFS1 and NDUFV1. Mitochondrion 21:33-40

Brandt U (2006) Energy converting NADH: Quinone Oxidoreductase (Complex I). Annu Rev Biochem 75:69-92

Calabrese R, Capriotti E, Fariselli P, Martelli PL and Casadio R (2009) Functional annotations improve the predictive score of human disease-related mutations in proteins. Hum Mutat 30:1237-1244

Consortium T 1000 GP (2015) A global reference for human genetic variation The 1000 Genomes Project Consortium. Nature 526:68-74

Fang F, Liu Z, Fang H, Wu J, Shen D, Sun S, Ding C, Han T, Wu Y, Lv J et al. (2017) The clinical and genetic characteristics in children with mitochondrial disease in China. Sci China Life Sci 60:746-757

Fassone E and Rahman S (2012) Complex I deficiency: Clinical features, biochemistry and molecular genetics. J Med Genet 49:578-590

Glusman G, Caballero J, Mauldin DE, Hood L and Roach JC (2011) Kaviar: An accessible system for testing SNV novelty. Bioinformatics 22:3216-3217

Hirst J (2013) Mitochondrial Complex I. Annu Rev Biochem $82: 551-575$

Incecik F, Herguner OM, Besen S, Bozdoğan ST and Mungan NO (2018) Late-onset Leigh syndrome due to NDUFV1 mutation in a 10-year-old boy initially presenting with ataxia. J Pediatr Neurosci 13:205-207.

Karczewski KJ, Francioli LC, Tiao G, Cummings BB, Alfoldi J, Wang Q, Collins RL, Laricchia KM, Ganna A, Birnbaum DP et al. (2020) The mutational constraint spectrum quantified from variation in 141,456 humans. Nature 581:434-443

Lek M, Karczewski KJ, Minikel EV, Samocha KE, Banks E, Fennell T, O’Donnell-Luria AH, Ware JS, Hill AJ, Cummings BB et al. (2016) Analysis of protein-coding genetic variation in 60,706 humans. Nature 536:285-291

Marin SE, Mesterman R, Robinson B, Rodenburg RJ, Smeitink J and Tarnopolsky MA (2013) Leigh syndrome associated with mitochondrial complex I deficiency due to novel mutations In NDUFV1 and NDUFS2. Gene 516:162-167

Murphy MP (2009) How mitochondria produce reactive oxygen species. Biochem J 417:1-13 
Nafisinia M, Guo Y and Dang X (2016) Whole Exome Sequencing Identifies the Genetic Basis of Late-Onset Leigh Syndrome in a Patient with MRI but little biochemical evidence of a mitochondrial disorder. JIMD Rep 32:117-124

Naslavsky MS, Yamamoto GL, de Almeida TF, Ezquina SAM, Sunaga DY, Pho N, Bozoklian D, Sandberg TOM, Brito LA, Lazar M et al. (2017) Exomic variants of an elderly cohort of Brazilians in the ABraOM database. Hum Mutat 38:751-763

Recalde O, Fonseca DJ, Patiño LC, Atuesta JJ, Riveira-Nieto C, Restrepo CM, Mateus HE, van der Knaap MS and Laissue P (2013) A novel familial case of diffuse leukodystrophy related to NDUFV1 compound heterozygous mutations. Mitochondrion 13:749-754.

Ramensky V, Bork P and Sunyaev S (2002) Human non-synonymous SNPs: server and survey. Nucleic Acids Res 30:3894-3900

Schuelke M, Smeitink J, Mariman E, Trijbels F, Stöckler-Ipsiroglu S and van den Heuvel L (1999) Mutant NDUFV1 subunit of mitochondrial complex I causes leukodystrophy and myoclonic epilepsy. Nat Genet 21:260-261

Schwarz JM, Cooper DN, Schuelke M and Seelow D (2014) Mutationtaster2: Mutation prediction for the deep-sequencing age. Nat Methods 11:361-362

Srivastava A, Srivastava KR, Hebbar M, Galada C, Kadavigrere R, Su F, Cao X, Chnnaivan AM, Girisha KM, Shukla A et al. (2018) Genetic diversity of NDUFV1-dependent mitochondrial complex I deficiency. Eur J Hum Genet 26:1582-1587

Taliun D, Harris DN, Kessler MD, Carlson J, Szpiech ZA, Torres R, Taliun SAG, Corvelo A, Gogarten SM, Kang HM et al. (2021) Sequencing of 53,831 diverse genomes from the NHLBI TOPMed Program. Nature 590:290-299
Van der Auwera GA, Carneiro MO, Hartl C, Poplin R, Angel GD, Levy-Moonshine A, Jordan T, Shakir K, Roazen D, Thibault J et al. (2013) From fastQ data to high-confidence variant calls: The genome analysis toolkit best practices pipeline. Curr Protoc Bioinforma 43:11.10.1-11.10.33

Varghese F, Atcheson E, Bridges HR and Hirst J (2015) Characterization of clinically identified mutations in NDUFV1, the flavinbinding subunit of respiratory complex I, using a yeast model system. Hum Mol Genet 24:6350-6360

Vilain C, Rens C, Aeby A, Balériaux D, Bogaert PV, Remiche G, Smet J, Coster RV, Abramowicz M, Pirson I. (2012) A novel NDUFV1 gene mutation in complex I deficiency in consanguineous siblings with brainstem lesions and Leigh syndrome. Clinical Genetics. 82:264-270.

Wadhwa Y, Rohilla S and Kaushik JS (2018) Cystic Leucoencephalopathy in NDUFV1 Mutation. Indian J Pediatr 85:1128-1131.

Zafeiriou DI, Rodenburg RJT, Scheffer H, van der Heuvel LP, Pouwels PJW, Ververi A, Athanasiadou-Piperopoulou $F$ and van der Knaap MS (2008) MR spectroscopy and serial magnetic resonance imaging in a patient with mitochondrial cystic leukoencephalopathy due to complex I deficiency and NDUFV1 mutations and mild clinical course. Neuropediatrics 39:172-175

Zhu J, Vinothkumar KR and Hirst J (2016) Structure of mammalian respiratory complex I. Nature 536:354-358

Associate Editor: Filippo Pinto e Vairo

License information: This is an open-access article distributed under the terms of the Creative Commons Attribution License (type CC-BY), which permits unrestricted use, distribution and reproduction in any medium, provided the original article is properly cited. 